\title{
Thoughts on Improving the Quality and Efficiency of Grass-roots Financial Management Under the New Situation
}

\author{
Zhengze Lu$^{1}$, Jianghua Huang ${ }^{2}$, Feng Tian ${ }^{3}$ \\ ${ }^{1}$ A Unit Of The Chinese People's Liberation Army In Xiamen, Fujian Province \\ ${ }^{2}$ A Unit Of The Chinese People's Liberation Army In Xiamen, Fujian Province \\ ${ }^{3}$ A Unit Of The Chinese People's Liberation Army In Xiamen, Fujian Province \\ *Corresponding author. Email: 763296140@qq.com
}

\begin{abstract}
Grass roots financial management is the terminal of fund implementation and the top priority of grass-roots security work. The quality and efficiency of its management is directly related to the use efficiency of grass-roots funds, and is bound to affect the quality of grass-roots construction. Starting with the main manifestations of the low efficiency of grass-roots financial management at present, this paper analyzes the specific reasons for the problems, and puts forward measures to improve the quality and efficiency of grass-roots financial management under the new situation from three aspects: opening up the closed link of grass-roots financial operation, refining and perfecting system norms, and improving the level of information office.
\end{abstract}

Keywords: Grassroots finance, Standardization, Management quality and efficiency.

\section{INTRODUCTION}

Under the current situation, the upper and lower levels generally devote more energy to organ fund management, while the focus on grass-roots funds only stays at the level of fund standards. With the geometric growth of grass-roots fund standards since the reform, the amount of funds in charge at the grass-roots level does not adapt to its actual management ability, the post pressure of grass-roots financial personnel does not match its work motivation The practical contradictions such as the disconnection between the reform of grass-roots financial system and the development of the current situation are becoming more and more intense, and the quality and efficiency difference of grass-roots fund management is becoming more and more significant, which has also had a very far-reaching impact on the quality and efficiency of grass-roots financial management and the quality of grass-roots construction. How to improve the quality and efficiency of grass-roots financial management is not only a huge problem faced by grass-roots units, but also a major bottleneck to improve grass-roots financial management. This paper introduces the main manifestations of the current low quality and efficiency of grass-roots financial management, analyzes the main reasons for the low quality and efficiency of grass-roots financial management, and puts forward some suggestions to improve the quality and efficiency of grass-roots financial management under the new situation, hoping to provide some help for readers to think about improving the quality and efficiency of grass-roots financial management under the new situation.

\section{AT PRESENT, THE MAIN PERFORMANCE OF LOW QUALITY AND EFFICIENCY OF GRASS-ROOTS FINANCIAL MANAGEMENT}

Since the Eighteenth National Congress of the CPC, grass-roots financial management has gradually changed to normalization, transparency and standardization. At present, the prominent problems in grass-roots financial management have also changed from repeated prohibition of discipline violations such as "micro corruption" to generally low quality and efficiency of grass-roots financial management, which are embodied in the following three aspects: 


\subsection{Money Is Not Spent}

The main performance is that the grass-roots level relies too much on the organs. Due to the "nanny" construction method of the organs for a long time, the grass-roots level has formed the habit of "spending money to find organs". Obviously, it can rely on its own funds, but it applies for funds from the organs. Finally, the quality of grass-roots construction is affected due to the long material procurement cycle.

\subsection{Money Is Wasted}

It is mainly manifested in the random use of grass-roots funds and the lax control of grass-roots leaders. For example, material procurement often thinks of what to buy and lacks overall planning, which eventually leads to idle and waste of material assets and low efficiency of fund output.

\subsection{No Money}

It is mainly manifested in the failure to live within our means and the implementation of plan management. For example, the board expenses have obviously exceeded the expenditure, but the savings plan has not been formulated in time, which eventually leads to the bitter fruit of excessive expenditure and can not be replenished in the short term.

\section{THE MAIN REASONS FOR THE LOW QUALITY AND EFFICIENCY OF GRASS-ROOTS FINANCIAL MANAGEMENT AT PRESENT}

The current regulations specify that the Party Committee organs shall not interfere with and arrange the matters that should be decided by the grass-roots level, so as to ensure the grass-roots level's overall arrangement right for daily work and the right to control the use of funds, materials and equipment. From the actual situation, the quality and efficiency of financial management under the operation mode of self construction at the grass-roots level is generally low, mainly due to the following three reasons:

\subsection{The Amount Of Funds In Charge At The Grass-roots Level Does Not Adapt To Its Actual Management Ability}

According to the current standards, the annual business expense income of grass-roots units is at least several times of the relevant business expense standards in the charge of many business departments of the organ, and the approval of the expenses of the business departments of the organ must be reviewed by the financial department and signed by the leaders of the Department or unit. According to the current documents, the grass-roots units are in charge of the funds, and the ownership and use right are at the grass-roots level, decision-making, use, review The review and signing authority is at the grass-roots level, and the financial department only performs the function of inspection and supervision ${ }^{[1]}$. However, due to the frequent post adjustment of grass-roots unit leaders and financial personnel, the professional ability of grass-roots financial personnel is limited, and the financial discussion and decision-making ability of grass-roots party committees and the review ability of grass-roots financial personnel are relatively weak.

\subsection{The Job Pressure Of Grass-roots Financial Personnel Does Not Match Their Work Motivation}

With the continuous efforts of building a clean and honest government, management measures for personnel in various sensitive posts and relevant provisions on mandatory job rotation have been issued one after another. The implementation of the document requires that grass-roots financial personnel should have both the professional ability to meet the needs of their posts and the adaptability to work quickly in new units, We should also have the ability to resist the risk of affecting personal growth and progress caused by frequent job rotation and frequent replacement of units. The actual situation is that most grass-roots financial personnel still hold the working mentality of "it doesn't matter if there are no problems or achievements". Compared with the continuous increase of work pressure, the working motivation continues to decline. For both subjective and objective reasons, the grass-roots financial personnel do not regard themselves as their own family members of the unit, only act as passers-by in their posts, only record daily accounts in their work, and only act as passers-by in their mentality ${ }^{[2]}$. Finally, they gradually become passive in financial management, affecting the quality and efficiency of grass-roots financial management.

\subsection{The Reform Of Grass-roots Financial System Is Divorced From The Development of The Current Situation}

After the reform, there has been a new situation in the grass-roots financial management, and the financial management power has been delegated to the grass-roots level, but the grass-roots financial management and supervision methods can not keep up with the new situation. First, the internal control of grass-roots fund management is not well implemented. According to the existing management authority, the decision-making of grass-roots fund use, audit, settlement and reimbursement are determined by the grass-roots themselves, which means that the grass-roots financial business personnel are both grass-roots fund 
managers and auditors. The internal financial control cannot be formed, and there are still loopholes in the grass-roots financial management system. Second, it is difficult to play a supervisory role. Due to the small number of financial personnel in the organ, it is difficult to complete their own business. The inspection of the use of funds of grass-roots units every half a year can only be casual. The inspection focuses on checking whether the expenditure items are correct and whether the procedures are complete, so they are unable to verify the authenticity of daily consumption.

\section{SUGGESTIONS ON IMPROVING THE QUALITY AND EFFICIENCY OF GRASS-ROOTS FINANCIAL MANAGEMENT UNDER THE NEW SITUATION}

\subsection{Open The Operation Closed Link}

Strive to build a closed operation link of "organization and leadership of the principal officials of the grass-roots party committees - direct management of the cadres in charge - specific implementation of the grass-roots financial personnel - counterpart guidance and guidance of the authorities", focusing on three tasks.

\subsubsection{Change Ideas}

First of all, we should change the ideological understanding of grass-roots leaders and let them realize that the Party committee is the main body of grass-roots financial management and the use of grass-roots funds. They are not only leaders but also responsible persons. We must strengthen the financial awareness of leaders, constantly strengthen the study of financial knowledge and regulations of grass-roots cadres, broaden their knowledge and improve their financial management ability $^{[3]}$.

\subsubsection{Clarify Their Respective Responsibilities}

It can be divided into four categories. (1) the leadership responsibility of grass-roots principal officials should make a good overall plan for the funds under their management, ensure that the fund investment is scientific and reasonable, and really make the limited funds produce the maximum economic benefits. (2) The main responsibility of the business handling personnel shall be familiar with the management regulations on the use of funds and the material procurement process, and be responsible for the authenticity of the procurement behavior. (3) The audit responsibility of grass-roots financial personnel is mainly to do a good job in fund audit and settlement, so as to ensure the authenticity of expense reimbursement bills, procedural compliance and perfect procedures. (4)
The supervision and guidance responsibilities of organs are mainly to refine the management methods for the use of grass-roots funds, guide the development of grass-roots financial work, implement regular inspection and correct problems in time.

\subsubsection{Improve Financial Management Ability}

Distinguish the two levels of grass-roots chief officers and grass-roots financial personnel, do a good job in training and improve the ability to perform their duties. (1) The grass-roots chief officer can increase the learning of grass-roots financial knowledge in the job training; Take financial management as an important assessment index for grass-roots leaders to improve their attention to grass-roots finance; In combination with the training of grass-roots cadres, timely organize the study of new financial regulations to improve the financial management ability of "being a family". (2) Grassroots financial personnel must have financial training experience in Colleges and universities to improve the entry threshold; Organize two business intensive training sessions every year, strengthen the basic ability training in the first half of the year, and analyze the key and difficult problems in the second half of the year to improve the post holding ability; Pay close attention to the implementation of the collective office system, regularly carry out account evaluation, timely organize experience introduction and problem analysis, and promote the ability of grass-roots financial personnel $^{[4]}$.

\subsection{Refine And Improve Institutional Norms}

This is a guarantee for managing grass-roots funds well. Two improvements should be made. First, refine the scope of grass-roots funds. We can refer to the regulations on the use of institutional expenses, formulate the detailed rules for the use of grass-roots funds, clarify the scope and standards of grass-roots funds procurement, eliminate over scope and over standard procurement, and ensure that grass-roots funds play a better role in serving the grass-roots level. Second, optimize the design of grass-roots financial management mechanism. Optimize the existing grass-roots fund management mechanism, further clarify the division of responsibilities and tasks of grass-roots financial personnel, separate grass-roots financial personnel from business operators, mainly responsible for fund audit, improve the internal control mechanism, and ensure the standardized and efficient use of grass-roots funds.

\subsection{Improve The Level Of Information Office}

The additional workload caused by the geometric growth of grass-roots funds has gradually overwhelmed the grass-roots financial personnel. It is urgent to 
establish information office conditions suitable for the new situation. At this stage, most of the units put into use are self-developed grass-roots financial management software, which is not systematic and has a single function. In particular, it lacks the function of online business processing and data sharing, resulting in low office efficiency ${ }^{[5]}$. It is suggested to improve the grass-roots informatization office level, reduce the work burden of grass-roots financial personnel, provide intuitive data for the financial decision-making of grass-roots party committees, and achieve the ultimate goal of improving the operation efficiency and management quality of grass-roots financial management.

\section{CONCLUSION}

It is urgent to improve the quality and efficiency of grass-roots financial management. Organs and grass-roots units must work together to improve the use efficiency of grass-roots funds, improve the quality and efficiency of grass-roots financial management, and ensure that grass-roots financial resources are transformed into combat effectiveness more timely, accurately and effectively by establishing a long-term operation mechanism, improving various systems and norms, and improving the level of information office.

\section{REFERENCES}

[1] Shaogang Zhang, Some thoughts on the innovation of military financial management under the new situation, Jiangxi Publishing Group Company, 2016.

[2] Xiaowei $\mathrm{Xu}$, Problems and improvement measures of military grass-roots financial management, Jilin Provincial Press and Publication Bureau, 2018.

[3] Ning Wang, This paper discusses the optimization strategy of military financial management in the new period, State Information Center, 2019.

[4] Xinwei Yang, Current situation and improvement of grass-roots financial management, State Information Center, 2015.

[5] Qiongfang Zhang, Thoughts on military financial management and support under the condition of modern informatization, Science and Technology Literature Press, 2018. 